\title{
Analysis on the Farmers' Satisfaction with Reform Experimentation of Rural Land Expropriation System
}

\section{-An Empirical Analysis for Liuyang}

\author{
Ninghui Li \\ School of Management, Jinan University, Guangdong, China \\ Email: Ninghui_Lee@163.com
}

How to cite this paper: Li, N.H. (2018) Analysis on the Farmers' Satisfaction with Reform Experimentation of Rural Land Expropriation System-An Empirical Analysis for Liuyang. Open Journal of Social Sciences, 6, 152-164.

https://doi.org/10.4236/jss.2018.61011

Received: January 4, 2018

Accepted: January 23, 2018

Published: January 26, 2018

Copyright $\odot 2018$ by author and Scientific Research Publishing Inc. This work is licensed under the Creative Commons Attribution International License (CC BY 4.0)

http://creativecommons.org/licenses/by/4.0/ Open Access

\begin{abstract}
Based on the data of farmers' survey and the reform practice in Liuyang city, which is one of the nation first experimentation regions of batch rural land system reform, this paper establishes the evaluation system of farmers' satisfaction, and analyzes the farmers' satisfaction and factors which influence farmers' satisfaction. The results show farmers' satisfaction of the reform is low and many segments urgently need to be further strengthened. Significantly, the low compensation standard is an important reason for the poor satisfaction of farmers. The five factors of farmers' hierarchy differentiation, including occupational diversification, income change, gender, age and education degree, all have a positive impact on farmers' satisfaction through disparate pathway. The implications are that every experimentation region should establish and improve dynamic update mechanism of land expropriation compensation standard and land expropriation decision-making mechanism, as well as improving farmers' security land-lost mechanism to achieve the further development of reform.
\end{abstract}

\section{Keywords}

Farmers' Satisfaction, Land Expropriation, System Reform, Affecting Factors

\section{Introduction}

Land expropriation is the only way to realize the conversion of farmland under Chinese current land system. The development of industrialization and urbanization is benefited from the farm land conversion and the rapid promotion of land value by the farmland conversion. The problems of the price distortion be- 
tween the land expropriation price and the market price, together with the imbalance of the increment income distribution of farmland have aroused wide attention from all sectors of society [1]. The primary market of land expropriation is monopolized by the government, and the land administration personnel have the greater discretion in the land expropriation, the resulting corruption cannot be ignored. Land expropriation easily leads to high risk of social stability [2], price distortion leads to low allocation efficiency of land resources [3]. Gradually reducing the scope of land expropriation, standardizing the procedures of land expropriation, improving the guarantee mechanism for landless farmers, and realizing the rational distribution of increment income are the topics in the reform of rural land expropriation system in China. No damage to the benefits of the farmers is one of the three major red lines that must be held in the reform of the rural land system. The basis for ensuring the farmers' interests includes fully respecting the farmers' will, ensuring the farmers' right to know, realizing the open land expropriation system and improving the satisfaction of farmers. In 2015, the Central Committee of the Communist Party of China and the State Council selected 33 counties (cities and flags) throughout the country as the first batch pilot areas for the reform of rural land system. Evaluating the farmers' satisfaction degree in the pilot area of land expropriation and exploring the factors that affect the satisfaction of farmers, are conducive to a reasonable assessment of the effectiveness of the reform of the rural land expropriation system, and can provide a reference for the scientific decision-making of the reform.

Farmers are an important subject of land expropriation, and the satisfaction of farmers is an important aspect to measure the effect of land expropriation, and it is also the focus of the academic study. At present, the satisfaction of land expropriation in China needs to be strengthened [4], and the evaluation of land expropriation system by farmers is affected by the system of land expropriation and its supporting system [5]. The compensation standard and the distribution mode of land expropriation compensation have an important influence on the satisfaction of farmers [6] [7] [8]. However, under the background of rapid urbanization, the market value of farmland is increasing, while the property income of farmers is relatively low. The land has certain social security functions [9], while only monetary compensation can result in farmers' satisfaction degree decline, previous studies have shown that social security along with compensation money can significantly improve the farmers' satisfaction [10]. Standardizing the land expropriation procedure is not only the guiding requirement of the construction of country's rural land expropriation system, but also the origin force of improving the satisfaction of the farmers. Liu et al. collected the samples containing 17 Chinese agricultural provinces, and found that the impartiality of land expropriation procedure was more effective than the compensation standard to improve the satisfaction of farmers [11]. Farmers' right to know and participation has a positive effect on farmers' satisfaction [12]. In addition, regional economic development level, location conditions, farmland dependence 
degree for farmers, land acquisition purpose and farmers' endowment characteristics have a certain degree of influence on farmers' satisfaction [13] [14] [15]. The current research has carried out a systematic study on the satisfaction of farmers, and explored the factors that affect the satisfaction of farmers in all directions. But the existing farmers' satisfaction study mostly comes from the subjective judgment of the farmers, and lacks the systematic measure index system. In view of the significant regional differences in land expropriation satisfaction, it is necessary to strengthen the empirical test of the influencing factors of different regional samples.

According to the above, this paper based on a survey data of Liuyang city, which is one of Chinese first pilot areas of batch rural land system reform, to construct the evaluation index system of farmers' satisfaction of rural land expropriation reform, carries out systematic analysis on farmers' satisfaction and its influencing factors. From the perspective of farmers' satisfaction, we evaluate the reform of the rural land expropriation system in Liuyang, in order to provide decision reference for the deepening of the reform of the rural land expropriation system.

\section{An Overview of the Reform Pilot Work}

Liuyang city is located in the eastern part of Hunan province, a population of 1 million 470 thousand, the area is $5007 \mathrm{~km}^{2}$, there are 32 towns, 322 villages (communities), 1 state-level economic development zones and 1 provincial-level high-tech zones. In 2017, the country economy of Liuyang ranked Seventeenth in China [16]. In March 2015, Liuyang was designated as a pilot county for the reform of rural homestead system in China. Since September 2016, it has also undertaken three important tasks of coordinating and promoting the reform of rural land system.

Liuyang has steadily promoted the reform pilot since charged the pilot task of the reform of the rural land expropriation system. There are formed four institutional results, including Pilot catalogue of land expropriation in liuyang, the risk assessment method of social stability of collective land requisition compensation and resettlement in Liuyang, measures for the management of land expropriation compensation funds in Liuyang, dispute coordination method of Land expropriation compensation and resettlement in Liuyang. These four institutional results fully protect the farmers' right to know and participate, creatively put forward the measure of "risk assessment a head" of land requisition, in other words, it put the risk of land expropriation before the transfer of land for approval, reducing the social stability risk of land expropriation. Liuyang have established and improved the multiple guarantee mechanism for farmers, such as the resettlement of reserved land and commercial and residential dual use, indemnificatory housing repurchase, employment training, urban workers' medical insurance and social endowment insurance. Liuyang has formed a set of replicable and popularized experience which contains reducing the scope of land 
expropriation, standardizing the procedures of land expropriation, and improving the security mechanism of landless farmers.

\section{Satisfaction Evaluation}

\subsection{Research Design and Sample Description}

In May 2017, the project team went to the Changxing community in Guanshan town and Beisheng town in yazhouhu village community both of them are typical demonstration area of rural land expropriation reform in Liuyang, conducted a field survey. We investigated by questionnaires and semi-structured interviews. Questionnaire mainly includes the satisfaction and influence factors, consists of 35 specific issues, specific satisfaction survey questionnaire design are shown in Table 1. The influence factors involved in farmers' gender, age, education, occupation, family size, income of last year, the social insurance and medical insurance, income change etc. A total of 350 questionnaires were issued in this survey, and 8 questionnaires were eliminated and 342 valid questionnaires were retained. The effective rate of the questionnaire was $97.71 \%$.

The sample selected as household unit, and one sample was extracted from each household. In principle, household head were selected. When household head were absent, family members with cognition were added. The respondents of survey were mainly male, accounted for $68.42 \%$, and young adults were relatively small, under 40 years of age of the respondents accounted for only $14.04 \%$, over 60 years of age of the respondents accounted for $29.82 \%$, the situation of elderly left behind is prominent. Interviewees are less educated, and the higher education was only accounted for $3.51 \%$. Expropriated farmers have generally realized the transformation from rural residents to urban residents, and the proportion of non-agricultural respondents reached $71.93 \%$. The annual income of the respondents concentrated in less than 20 thousand yuan and accounted for $61.40 \%$. The coverage rate of medical insurance and social security was $85.96 \%$ and $64.91 \%$ respectively. Only $22.81 \%$ of the interviewees were protected by a small number of contracted land, and $77.19 \%$ respondents were all expropriated of cultivated land.

\subsection{Index System and Research Method}

Combined with the existing research results and the practice of rural land expropriation system reform, we construct farmers' satisfaction evaluation system from three aspects, including satisfaction of safeguarding of right to know, satisfaction of compensation standards, satisfaction of dispute disposal. There are 3 index levels, 21 factor levels, and each index is positive index (Table 2). We use the analytic hierarchy process to determine the weight of each index, and the specific weight of the index is shown in Table 2. The establishment of index weight is mainly based on the following aspects: the difference between urban and rural development in China is large, farmers' money income is low, and so the social security function of land is still outstanding. Therefore, farmers have 
Table 1. Satisfaction index assignment.

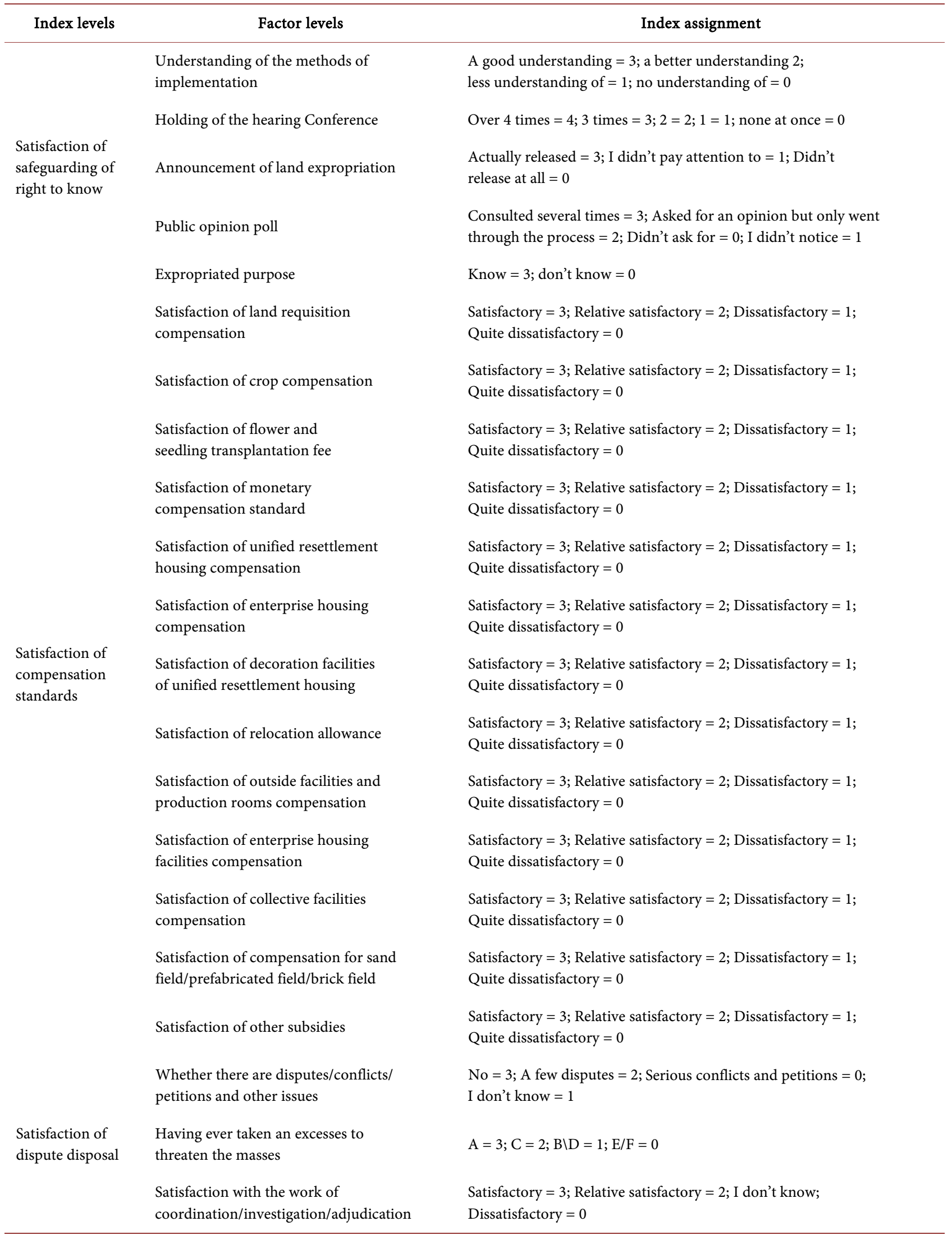


Table 2. Satisfaction evaluation system.

\begin{tabular}{|c|c|c|c|}
\hline Index levels & Factor levels & Mean Value & standard deviation \\
\hline \multirow{5}{*}{$\begin{array}{l}\text { Satisfaction of } \\
\text { safeguarding } \\
\text { of right to } \\
\text { know }(0.31)\end{array}$} & Understanding of the methods of implementation (0.52) & 0.72 & 1.00 \\
\hline & Holding of the hearing Conference $(0.12)$ & 0.74 & 1.17 \\
\hline & Announcement of land expropriation (0.12) & 1.77 & 1.31 \\
\hline & Public opinion poll (0.12) & 1.40 & 1.19 \\
\hline & Expropriated purpose $(0.12)$ & 0.91 & 0.29 \\
\hline \multirow{13}{*}{$\begin{array}{l}\text { Satisfaction of } \\
\text { compensation } \\
\text { standards }(0.58)\end{array}$} & Satisfaction of land requisition compensation (0.38) & 0.86 & 0.88 \\
\hline & Satisfaction of crop compensation (0.08) & 0.89 & 0.79 \\
\hline & Satisfaction of flower and seedling transplantation fee (0.03) & 0.88 & 0.68 \\
\hline & Satisfaction of monetary compensation standard $(0.14)$ & 0.91 & 0.85 \\
\hline & Satisfaction of unified resettlement housing compensation (0.14) & 1.11 & 0.94 \\
\hline & Satisfaction of enterprise housing compensation (0.02) & 0.96 & 0.60 \\
\hline & Satisfaction of decoration facilities of unified resettlement housing $(0.04)$ & 1.25 & 1.01 \\
\hline & Satisfaction of relocation allowance $(0.03)$ & 1.00 & 0.85 \\
\hline & Satisfaction of outside facilities and production rooms compensation $(0.06)$ & 1.11 & 0.99 \\
\hline & Satisfaction of enterprise housing facilities compensation (0.02) & 0.93 & 0.59 \\
\hline & Satisfaction of collective facilities compensation $(0.04)$ & 0.98 & 0.67 \\
\hline & Satisfaction of compensation for sand field/prefabricated field/brick field (0.01) & 0.93 & 0.56 \\
\hline & Satisfaction of other subsidies $(0.01)$ & 0.96 & 0.68 \\
\hline \multirow{3}{*}{$\begin{array}{l}\text { Satisfaction } \\
\text { of dispute } \\
\text { disposal }(0.11)\end{array}$} & Whether there are disputes/conflicts/ petitions and other issues $(0.32)$ & 1.25 & 1.29 \\
\hline & Having ever taken an excesses to threaten the masses $(0.43)$ & 1.14 & 1.32 \\
\hline & Satisfaction with the work of coordination/investigation/adjudication (0.25) & 0.74 & 0.84 \\
\hline Overall satisfaction & & 0.96 & 0.51 \\
\hline
\end{tabular}

higher psychological expectation for the land compensation standards. Indeed, the land expropriation compensation can realize part of value of rural land, but there is still a gap between the compensation standard and the market value of the land. The fairness of land income distribution needs to be strengthened. The difference between the psychological expectation and the actual compensation of farmers' land will significantly affect the satisfaction of farmers [17] [18]. Therefore, the standard of compensation is the most important factor for the satisfaction of farmers. Protecting farmers' right to know and participate, especially the right to participate in land compensation standard formulation, can effectively enhance farmers' sense of participation, subjectivity and self-determination, and then improve farmers' satisfaction. Therefore, the protection of the right to know has an important impact on the satisfaction of farmers. The dispute is the negative externality of land expropriation, and the disputed disposal is directly related to the social stability risk of land expropriation [19]. Although the disputes (conflicts) in land expropriation are highly influential and widely spread, 
the dispute (conflict) is still a contingency in the reform of land acquisition system in Liuyang. Therefore, the weight of dispute disposal is relatively small in the farmer's satisfaction evaluation system.

The comprehensive evaluation method is used to measure the overall satisfaction of farmers' land expropriation. The concrete formula is as follows:

$$
P S D_{i}=\sum_{i=1}^{n} X_{i j} W_{i j}, i=1,2,3, \cdots, n
$$

$P S D_{i}$ represents overall satisfaction index of sample $i, X_{i j}$ represents the satisfaction score for $j$ sub item of sample $i, W_{i j}$ represents the weight for $j$ sub item of sample $i$. $n$ is sample size, $n=342$ in this research.

\subsection{Satisfaction Evaluation}

The index is an integer between [0,3], and most of the gradient is 1 . Specific index assignment is shown in Table 1. The measurement results of Liuyang show that the overall satisfaction of farmers is low, and many segments need to be further strengthened. Only a few of sub item have higher satisfaction (the satisfaction index was higher than 1), such as announcement of land expropriation, public opinion poll, satisfaction of unified resettlement housing compensation, satisfaction of decoration facilities of unified resettlement housing, Satisfaction of relocation allowance, satisfaction of outside facilities and production rooms compensation, whether there are disputes/conflicts/petitions and other issues, having ever taken an excesses to threaten the masses. While the scores of farmers' satisfaction in the other 15 sub items are less than 1 , needs to be further strengthened (Table 2). There are greater differences among different levels for the satisfaction of farmers. The satisfaction of disputed disposal was 1.073, the satisfaction of protection of the right to know and the satisfaction of the compensation standard are relatively low, the satisfaction of the compensation standard is only 0.949. The compensation standard is the most important part of the farmers. In our field research, the project team found that farmers generally prefer the mode of land resettlement, to some extent; it also reflects the gap between the current compensation standard and farmers' psychological expectations. It can be seen that the low compensation standard is an important reason for the poor satisfaction of farmers.

It is quite puzzling that the satisfaction of farmers' right to know is also low. Generally, the items in factor level of the satisfaction safeguarding of right to know are easy to implement in the reform pilot work. But the statistical results show: $17.55 \%$ of the respondents was completely unknown or not well understood the land requisition compensation and the implementation of resettlement measures; $5.26 \%$ of the respondents said that the hearing was not held at once, but the actual situation of Liuyang city is that the hearing held times were more than 4 times; and $36.84 \%$ of the people said that some administrative authorities had not consulted the farmers before issuing land compensation and resettlement programs. 


\section{Analysis of Influencing Factors}

Farmers' satisfaction reflects the effect of rural land expropriation system reform, and farmers are important participants in agricultural land reform, but not the passive recipients of reform. As an individual, farmers are the owners of the property rights of land expropriated. Many farmers together constitute the basic unit of rural governance in China. The rural destiny community built by the unique geography, blood and occupation relationship, and its embedded trust mechanism and reciprocal mechanism, will further strengthen the role of farmers in the reform of the rural land expropriation system. Therefore, it is of great significance to clarify the influencing factors of farmers' satisfaction, and explore the direction and path of the influencing factors.

\subsection{Model Selection and Variable Description}

We use multivariate linear regression model in econometrics to study the influencing factors of farmers' satisfaction. The specific formula is as follows:

$$
Y=\beta_{0}+\sum_{i=1}^{n} \beta_{i} X_{i}+\epsilon
$$

$Y$ represents the satisfaction of farmers, $X_{i}$ represents indicators of influencing factors for farmers' satisfaction, $\beta_{0}$ represents intercept item; $\beta_{i}$ represents regression coefficient of factors influencing factors of farmers' satisfaction; $\epsilon$ represents random disturbance item.

Referring to the existing research results, starting from the reform practice, combined with the characteristics of farmers, this paper selects 10 variables from the aspects of farmers' differentiation characteristics, social security characteristics, intensity of the expropriation, and income changes. The results of variables and their statistical analysis are shown in Table 3.

\subsection{Empirical Results Analysis}

In order to examine the degree of action of variables (influencing factors), and to test the level of robustness of variables, this study uses item by item method to carry out metrological regression test. Model 1 is the basic model of adding control variables. Model 2, model 3, model 4 and model 5 successively add the variables of household differentiation, social security, intensity of the expropriation and income change. The regression results of the specific model are shown in Table 4.

The regression results show that occupational variable have passed $1 \%$ significant level tests, and the coefficient is positive, that is, the occupational variable has a positive effect on farmers' satisfaction. The higher the degree of farmers' transformation of non-agriculture, the higher the farmers' satisfaction is. The reason may be that different classes of farmers inevitably have differences in preference and net income function. For non-agricultural occupation, the reform of land expropriation system may be one more way to bring economic 
N. H. Li

Table 3. Variable assignment and statistical analysis of influencing factors.

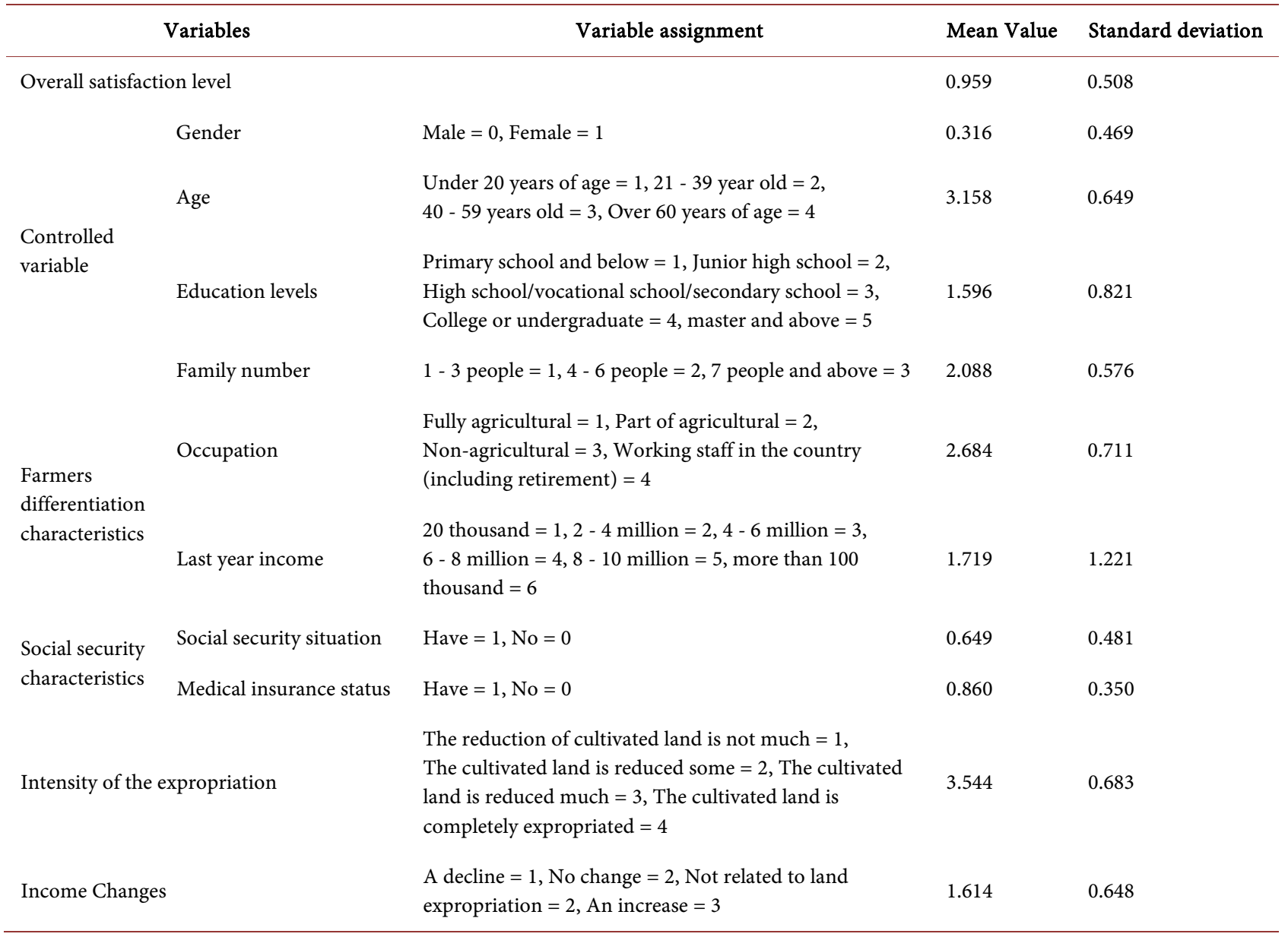

Table 4. Model regression results.

\begin{tabular}{|c|c|c|c|c|c|c|}
\hline \multicolumn{2}{|l|}{ Variables } & Model 1 & Model 2 & Model 3 & Model 4 & Model 5 \\
\hline \multirow{3}{*}{ Controlled Variable } & Gender & $0.199^{* * *}$ & $0.195^{* * *}$ & $0.173^{*}$ & $0.161^{*}$ & $0.151^{*}$ \\
\hline & Age & $0.330^{* * *}$ & $0.288^{* * *}$ & $0.267^{* * *}$ & $0.260^{* *}$ & $0.255^{* * *}$ \\
\hline & Education levels & $0.263^{* * *}$ & $0.239^{* * *}$ & $0.226^{* * *}$ & $0.229^{* * *}$ & $0.204^{* *}$ \\
\hline \multirow{3}{*}{ Farmers differentiation characteristics } & Family number & 0.128 & 0.018 & 0.034 & 0.028 & 0.017 \\
\hline & Occupation & & $0.217^{* * *}$ & $0.206^{* * *}$ & $0.212^{* * *}$ & $0.233^{* * *}$ \\
\hline & Last year income & & 0.040 & 0.041 & 0.040 & 0.057 \\
\hline \multirow{2}{*}{ Social security characteristics } & Social security situation & & & 0.080 & 0.088 & -0.006 \\
\hline & Medical insurance status & & & 0.023 & 0.021 & 0.089 \\
\hline \multicolumn{2}{|c|}{ Intensity of the expropriation } & & & & -0.024 & 0.008 \\
\hline \multicolumn{2}{|c|}{ Income Changes } & & & & & $0.198^{* *}$ \\
\hline \multicolumn{2}{|l|}{ Adj R-square } & 0.276 & 0.353 & 0.333 & 0.320 & 0.379 \\
\hline \multicolumn{2}{|l|}{ _cons } & $-0.849^{* *}$ & $-1.106^{* * *}$ & $-1.088^{* * *}$ & $-0.985^{*}$ & $-1.425^{* * *}$ \\
\hline \multicolumn{2}{|l|}{$\mathrm{N}$} & 342 & 342 & 342 & 342 & 342 \\
\hline
\end{tabular}

Note: ${ }^{* *},{ }^{* *},{ }^{*}$ represent the test of significant level was passed under the significant level of $1 \%, 5 \%$ and $10 \%$ respectively. 
benefit, especially the a few of respondents' family income does not rely on land resources, and so the land expropriation have less effect on their family income. But for the vulnerable groups (complete farming households), land resources is the foundation for them survive. The occupational differentiation of farmers not only reflects the degree of farmers' dependence on the land, but also causes the income expectation difference of farmers, and indirectly affects the satisfaction of farmers. The heterogeneity of the farmers' group leads to the diversification of the stand in the reform. At the same time, the income level of farmers did not pass the test of significant level. The reason may be that the income gap between the respondents is not large, and the greater impact on farmers' satisfaction is not absolute income, but the expectation income of land expropriation.

It is regrettable that the characteristics of social security and the intensity of land expropriation are not passed the significance test. The level of social security cannot better enhance the satisfaction of farmers. It reflects the fact that there is a certain gap between land acquisition compensation and protection function of farmers' land in Liuyang. It also reflects the objective reality that farmers in China have a high reliance on land because of the limited property income. To a certain extent, the intensity of land expropriation is a related variable of land dependence of farmers. The proportion of land completely expropriated in the respondents is $93.62 \%$, which lacks the main reference objects, and does not show obvious regularity. But Guo et al. hold the view that the intensity of land expropriation has a negative impact on the satisfaction of farmers.

The variable of income change passed the $5 \%$ level of significance test, and the coefficient is positive. It can be seen that the income changes caused by the land expropriation seriously affect the satisfaction of farmers. Farmers' satisfaction come from the income increasing due to land expropriation is much higher than that of other items. The demand of farmers is increasingly diversified, but the direct economic incentive is still the key factor to improve the satisfaction of farmers.

Regression results with control variables showed that gender, age and educational level variables all passed the test of significant level. Only family variables did not pass significant level test. The gender variable has a positive impact on the farmers' satisfaction, but with the addition of characteristics of social security, the intensity of expropriation, the change of income and so on, the level of significance and the degree of impact have declined in varying degrees. The regression coefficient indicates that the satisfaction of male farmers is higher than that of female farmers. Both age variable and educational level variable have a positive impact on farmers' satisfaction. Due to the age, the benefits that old people can obtain from the land are limited, so they have higher degree of satisfaction. The higher of education level, the stronger of earning ability. Therefore, the farmers of a higher education level have a more supportive attitude towards the reform of the land expropriation system, and their satisfaction is also higher. The test of family population variable did not pass the significant level. The rea- 
son may be that the amount of land contracted is positively correlated with the number of family members, and the land expropriation compensation policy is a good trade-off between the number of land expropriation and the size of family population.

\subsection{Robustness Test}

We classify farmers based on the time and area of land expropriation, and according to the above method, we carried out the regression analysis, and test for robustness of the results. The results of this study are relatively robust. At the same time, it also shows that the influencing factors of farmers' satisfaction are quite consistent with different time and farmers in different areas. It shows that the categories, directions and paths of influencing factors are relatively stable during the period of investigation.

\section{Conclusions and Policy Implication}

Based on the survey data of farmers in Liuyang, this paper systematically analyzes the reform work of Liuyang, then evaluates the satisfaction of expropriation of farmers, and explores factors influencing farmers' satisfaction. The main conclusions as follows:

1) Since Liuyang city undertook the reform task, it has formed 4 major institutional results. The land expropriation catalogue has been formulated and the land expropriation procedure has been standardized. In general, it has established and improved the multi protection mechanisms of farmers, and achieved certain results.

2) The overall satisfaction of farmers in the rural land expropriation reform needs to be improved. The average satisfaction of farmers is only 0.96 and many segments need to be further strengthened. There is a big difference in each index level, and the satisfaction of compensation standard is the lowest, which is only 0.949. In the pilot work of the land expropriation, the hearing is insufficient, and the farmers' inquiry work needs to be further improved.

3) The index of farmers' differentiation, income change, gender, age and education level have different influence on the farmers' satisfaction. Through two paths which contain land dependence and the bias between expected and actual income of farmers, farmers' occupational differentiation exerts a positive effect on the satisfaction of farmers. The characteristics of social security, the intensity of expropriation and the number of family population have not passed the test of significant level.

In order to achieve better output and quality of the reform and make reform pilot work of the rural land acquisition system can be copied, the pilot areas need from the local reality, working mechanism, management system, system innovation, and so on to enhance the effectiveness of farmers' satisfaction in reform. According to the conclusion, the following suggestions are put forward: (1) The low overall satisfaction suggests that the government should fully pro- 
tect the farmers' dominant role, keep farmers' main role in negotiations, and should strengthen management from all aspects, such as protecting the right of participating in the formulation and revision plan to improve transparency of land expropriation, and expanding the scope of the audience of announcement, hearing conference and consult to improve farmers' sense of participation; (2) The fact of the variable of income change is an influence factor while the variable of social security is not an influence factor suggesting that farmers prefer to acquire sustainable income from land expropriation, and to some extent, reflecting that the social security system established by land expropriation has low level of protection, which is difficult to meet the growing needs of farmers. So the government not only should fully respect farmers' willing, scientifically drawing up the compensation standard of land expropriation, and establishing and improving the dynamic update mechanism of compensation standard based on marketing price, but also should speed up the promotion and improvement of the social security system of the land expropriation, raise security funds through multiple channels, raise the level of protection, fully guarantee non-agricultural employment of the land lost farmers and the livelihood of farmers; (3) In addition, we also note that some of the control variables have a significant impact on satisfaction, such as occupation differentiation, gender, age and education level. The heterogeneity of the farmers' group leads to the diversification of the compensation demand in the reform. The government should take full account of the characteristics of farmers themselves, enriching the way of compensation for land expropriation, and formulate and implement land expropriation compensation policies according to local conditions.

The limitation of this research is that the evaluation of farmers' satisfaction of land expropriation is mainly based on some intuitive quantitative indicators, and lacks in-depth analysis and demonstration for a systematic index system reflecting farmers' satisfaction of land expropriation.

\section{References}

[1] Liu, S.Y. (2014) Characteristics, Problems and Reform of China's Dual Urban-Rural Landtenure. International Economic Review, No. 3, 9-25.

[2] Wang, L.J., Cheng, X.W., Liu, C., et al. (2014) The Study of Social Stability Risk Assessment under Current Rural Land Expropriation. China Land Sciences, 28, 19-29.

[3] Wang, L.J., Han, X.H., Li, H., et al. (2014) Empirical Study of the Influential Factors and Performance Evaluation of Land Supply. China's Population, Resources and Environment, 24, 121-128.

[4] Zhang, M.L. and Chen, L.G. (2008) Land Expropriation Relief: Performance Analysis and Mechanism Improvement-An Empirical Study Based on Jiangsu Province. Rural observation in China, No. 6, 5-27.

[5] Ji, X.Q. and Qian, Z.H. (2011) Assessing the Satisfaction at Land Expropriation System from the Perspective of Land-Lost Farmers: Evidence from Jiangsu Province. China Land Sciences, 25, 8-13.

[6] Guo, L.X., Gao, G.X. and Peng, K.L. (2012) Research on the Affecting Factors of Landless Farmers' Land Acquisition Will Based on Logistic Model. Resources Sci- 
ence, 34, 1484-1492.

[7] Liu, Y. (2016) Research on Farmers' Satisfaction of Land Acquisition Compensation in under Development Area: A Case Study of Southeast Region of Guizhou Province. Guizhou Ethnic Studies, 37, 42-46.

[8] Wang, L.J., Wu, J.H. and Li, H. (2013) A Regional Comparison of Farmers' Willingness to Land Expropriation and Its Influencing Factors. Rural Observation in China, No. 1, 11-20.

[9] Jin, L.G. and Huang, L.X. (2014) Study on Micro-Foundation Mechanism of Land Policies into Macroeconomic Regulation. Science and Technology Management Research, 34, 171-175.

[10] Qu, S. and Xia, Y. (2015) Comparison of Farmers' Satisfaction with Different Compensation Modes of Rural Land Expropriation. Agricultural Science in Guangdong, 42, 166-171.

[11] Liu, X.Q., Chen, Z. and Zhao, Y. (2012) The Procedural Fairness Prior to the Monetary Compensation: The Determinants of the Degree of Farmers' Satisfaction at Levying Their Land. Management World, No. 2, 44-51.

[12] Liu, X.N., Lv, T. and Yan, S.Q. (2016) Study on the Procedural Rights Guarantee and Farmers' Satisfaction in the Process of Land Acquisition: Based on the Investigation of 30 Villages, 6 Cities in Liaoning Province. China Land Sciences, 30, 21-28.

[13] Ma, X.M. and Zhang, A.L. (2016) Regional Differences and Farmers' Satisfaction on Land Expropriation Compensation. Journal of South China Agricultural University (Social Science Edition), 15, 58-69.

[14] Chen, Z.F. (2013) Study on the Life Satisfaction of the Landless Peasants in the Process of Urbanization in China. Journal of Chinese Academy of Governance, No. 1, 55-62.

[15] Li, S.P., Luo, B.L. and Zhong, W.J. (2013) Intensity of Property Rights, Resource Endowments and Satisfaction of Land Requisition-Based on Nationwide Sampling Survey of 273 Farmers. Journal of Huazhong Agricultural University (Social Sciences Edition), No. 5, 7-15.

[16] Saidi, A. (2017) White Paper of China's Top 100 on the County Economy in 2017. http://news.officese.com/2017-7-15/65013.html

[17] Cheng, Y. and Zhang, A.L. (2007) Investigation on the Land Requisition in the Urban Fringe of Wuhan City-According to the Questionnaire of Present and Village Leader. Rural Observation in China, No. 5, 11-21.

[18] Cheng, Y., Tan, S.K. and Zhang, A.L. (2009) Study on the Difference of Land Expropriation Compensation for Public Welfare and No Public Welfare-An Empirical Study Based on 543 Household Questionnaires and 83 Collection Cases of 54 Villages in 4 Cities of Hubei. Management World, No. 10, 72-79.

[19] Washburn, V.J. (2011) Regular Takings or Regulatory Takings: Land Expropriation in Rural China. Pacific Rim Law \& Policy Journal Association, 20, 73-81. 